\title{
Exposure Dose Adjustment
}

National Cancer Institute

\section{Source}

National Cancer Institute. Exposure Dose Adjustment. NCI Thesaurus. Code C83061.

An indication or description that an exposure dosage was adjusted. 